\title{
Rancang Bangun Sistem Akses Rumah Indekos Menggunakan QR Code Berbasis Mikrokontroler dengan Payment Reminder System pada Aplikasi Android
}

\author{
Aisyah Nanda Kartina'), Mila Kusumawardani'), Rachmad Saptono ${ }^{3)}$ \\ ${ }^{1,3}$ Program Studi Jaringan Telekomunikasi Digital, \\ ${ }^{2}$ Program Studi Teknik Telekomunikasi, \\ Jurusan Teknik Elektro, Politeknik Negeri Malang, Indonesia \\ 19aisyahnandakartina@gmail.com, ${ }^{2}$ mila.kusumawardani@polinema.ac.id, ${ }^{3}$ rachmad.saptono@polinema.ac.id
}

\begin{abstract}
The boarding house is a temporary residence and is used as a place to store valuables. One of the facilities that need to be improved is the security of the fence and door of the house, because houses are often targets for people who want to commit crimes, so a security system is needed. The majority of security systems on house door locks are currently manual security systems in the form of conventional padlocks. This study aims to develop a system to provide a better level of security accuracy on room doors and boarding house fences, and a payment reminder system so that boarding house payments are more controlled. To open the fence and door of the boarding house occupants, scan the $Q R$ code with the android application so that they can access the fence and door of the room. Status has not paid the rent will be given a warning in the form of a pop-up in the android application. The test results obtained are in the form of successful testing of the functionality of the miniature boarding house, testing the SmartKos application, firebase database, and the accuracy of data communication between firebase and NodeMCU in the form of delay with the worst value in the measurement. 3 rd with a value of $3.89 \mathrm{~s}$, the best throughput is in the 3rd measurement with a value of 43864 bps, packet loss in this study has an index of 4 because it has a packet loss value of $0 \%$..
\end{abstract}

Keywords-Access System, QR Code, NodeMCU, Android

Abstrak - Rumah indekos merupakan tempat tinggal sementara dan dijadikan sebagai tempat untuk menyimpan barang-barang berharga. Salah satu sarana yang perlu ditingkatkan adalah keamanan pagar dan pintu rumah, karena rumah seringkali menjadi sasaran bagi orang yang ingin berbuat kejahatan, sehingga sistem keamanan sangat dibutuhkan. Salah satu cara yang bisa dilakukan untuk mengamankan pagar dan pintu rumah adalah menggunakan kunci pintu digital. Sistem keamanan pada kunci pintu rumah disaat ini mayoritas ialah sistem keamanan manual berbentuk kunci gembok konvensional. Penelitian ini bertujuan untuk melakukan pengembangan sebuah sistem untuk memberikan tingkat akurasi keamanan yang lebih baik pada pintu kamar dan pagar indekos, dan sistem pengingat waktu pembayaran agar pembayaran indekos lebih terkontrol. Untuk membuka pagar dan pintu kamar penghuni indekos melakukan pemindaian kode QR dengan aplikasi android sehingga dapat mengakses pagar dan pintu kamar tersebut. Penghuni indekos yang statusnya belum membayar uang sewa akan diberi peringatan berupa pop up di aplikasi android. Setelah dilakukan pengujian sistem miniatur rumah indekos, maka didapatkan hasil pengujian yaitu berupa keberhasilan uji fungsionalitas miniatur rumah indekos yang telah dibuat, uji fungsionalitas aplikasi SmartKos pada smartphone android, database firebase, dan keakuratan komunikasi data antara firebase dan NodeMCU berupa delay dengan nilai terburuk pada pengukuran ke-3 dengan nilai 3.89 detik, throughput yang paling baik adalah pada pengukuran ke-3 dengan nilai 43864 bps, packet loss pada penelitian ini memiliki indeks 4 karena memiliki nilai packet loss sebesar $0 \%$.

Kata kunci-Sistem Akses, QR Code, NodeMCU, Android

\section{PENDAHULUAN}

Seiring berkembangnya zaman banyak sekali rumah-rumah yang dijadikan sebagai persewaan tempat tinggal, yaitu seperti rumah indekos. Menurut Kamus Besar Bahasa Indonesia [1], indekos adalah tinggal di rumah orang lain tanpa makan ataupun dengan makan dan melakukan pembayaran tiap bulannya. Sedangkan menurut Utomo dalam artikelnya yaitu mengenai tempat indekos atau sering disebut kos-kosan merupakan sejenis kamar sewa yang di-booking dalam kurun waktu tertentu. Biasanya booking kamar dilakukan dalam kurun waktu tiga bulan bahkan satu tahun serta memiliki fungsi sebagai rumah tinggal sementara [2]. Kunci rumah merupakan pemegang peranan penting pada sistem keamanan rumah. Sistem keamanan rumah yang kurang terjaga menyebabkan rumah menjadi target pencurian atau tindak kejahatan lain sejenisnya. Oleh karena itu, keamanan rumah sangat diperlukan dan bersifat mutlak [3].

Pagar indekos merupakan keamanan yang paling utama dalam menjaga rumah indekos dengan menggunakan berbagai jenis kunci tambahan. Sedangkan pintu kamar indekos merupakan akses yang dipakai untuk dapat menempati kamar yang sudah disewa dalam bulanan atau tahunan, tetapi banyak 
pintu kamar indekos saat ini yang masih menggunakan kuncikunci standard. Dengan adanya permasalahan dalam melakukan akses rumah indekos yang masih menggunakan kunci konvensional maka diperlukan sebuah sistem untuk memberikan tingkat akurasi keamanan yang lebih baik. Di sisi lain juga terdapat beberapa kamar indekos yang dikelola oleh pemiliknya, hal tersebut menyebabkan permasalahan dalam pembayaran sewa kamar indekos, pemilik indekos harus mencatat bukti-bukti pembayaran penghuni indekos ke dalam sebuah buku atau kwitansi, pemilik indekos harus rutin melakukan penagihan pembayaran pada bulan berikutnya dan kondisi buruknya adalah ketika penghuni indekos yang nunggak saat membayar. Dengan adanya pengelolaan agar pemilik indekos dapat mengontrol masa sewa pembayaran kamar, maka muncul ide untuk perancangan aplikasi pengingat pembayaran pada rumah indekos. Sistem pengingat ini bertujuan untuk memperingatkan penghuni indekos ketika masa sewa kamar akan habis sesuai jangka waktu persewaan kamar indekos yang telah dilakukan [4].

Berdasarkan permasalahan tersebut, maka skripsi ini mengajukan judul mengenai Rancang Bangun Sistem Akses Rumah Indekos Menggunakan QR Code Berbasis Mikrokontroler Dengan Payment Reminder System Pada Aplikasi Android pada penelitian ini akan dirancang sebuah miniatur sistem keamanan untuk akses pintu kamar dan pagar indekos meggunakan QR Code. QR Code dipindai menggunakan aplikasi android yang telah dibuat sesuai data penghuni indekos yang telah terdaftar di database, selain itu pada aplikasi android juga akan diberikan sistem peringatan pembayaran pada penghuni indekos untuk melakukan pembayaran sesuai waktu yang ditentukan.

Penelitian dengan judul Implementasi Prototype Sistem Home security dengan Pemanfaatan Kode Akses berbasis Arduino Mega, pada penelitian ini membahas tentang perancangan dan realisasi sistem home security, dengan arduino yang dapat mengendalikan kerja sistem home security tersebut yang diawali saat pemberian akses kode dengan benar sampai pemberian akses kode yang salah. Penggunaan teknologi password pada penelitian ini memiliki kekurangan bahwa harus menekan tombol berkali-kali sehingga membuat tidak nyaman belum lagi jika memasukkan password yang salah dan bahkan lupa akan password tersebut [5].

Penelitian dengan judul Alat Kontrol Akses Pintu Rumah dengan Teknologi Sidik Jari di Lingkungan Rumah Pintar dengan Data yang Dienkripsi, dalam penelitian ini membahas tentang implementasi sidik jari pada mikrokontroler Arduino untuk membangun miniatur penguncian pintu rumah atau garasi. Penelitian ini memiliki kelemahan apabila jari yang akan dideteksi dalam kondisi basah, kotor atau berkeringat yang dapat menyebabkan lambatnya proses akses pintu rumah, karena pemindai sidik jari juga sangat sensitif yang dapat membuat proses pengenalan sulit dilakukan [6].

Penelitian dengan judul Rancang Bangun Pintu Otomatis Menggunakan Arduino Uno dan PIR (Passive Infra Red) Sensor di SMP Negeri Simpang Semambang, pada sistem pintu otomatis ini dirancang dengan menggunakan kendali otomatis yang dipadu dengan sensor dan motor servo. Input yang digunakan yaitu sensor PIR (Passive InfraRed Receiver) yang dapat mendeteksi adanya pergerakan manusia yang akan mendekati pintu. Kelemahan dari penggunaan sensor PIR ini kurang dalam segi keamanan yang dapat mendeteksi gerakan manusia sehingga siapa saja yang mendekati sensor pintu akan terbuka secara otomatis [7].

Penelitian dengan judul Rancang Bangun Akses Kontrol Pintu Gerbang Berbasis Arduino dan Android, penelitian ini bertujuan untuk membuat alat kontrol pintu berbasis Arduino Uno dan Android untuk keamanan rumah yaitu pintu gerbang secara otomatis tanpa harus menggunakan kunci standard. Pada penelitian ini menggunakan teknologi bluetooth yang memiliki kelemahan yaitu tidak adanya algoritma pemograman untuk sistem proteksi dan teknologi sebagai pengaman pintu, sehingga ketika smartphone yang digunakan untuk kontrol pintu otomatis hilang, maka harus dilakukan pemrograman ulang pada board Arduino dan Android supaya alat ini dapat digunakan sebagaimana mestinya serta sifat komunikasi bluetooth yang hanya satu arah sehingga penggunaan multi user tidak dapat dilakukan [8].

Penelitian dengan judul Implementation of Intelligent Automated Gate System with QR Code, tujuan dari penelitian ini adalah untuk mengembangkan dan mengimplementasikan jenis sistem gerbang keamanan tingkat menengah terutama untuk perusahaan kecil yang tidak mampu memasang sistem gerbang otomatis berteknologi tinggi. Kelemahan sistem gerbang ini masih menggunakan aplikasi perangkat lunak VB.NET sehingga sistem kontrol dapat dilakukan hanya melalui komputer/PC [9].

\section{METODE}

\section{A. Blok Diagram Sistem}

Rancangan yang akan dibuat untuk memudahkan perancangan sistem diperlukan sebuah diagram blok sistem.

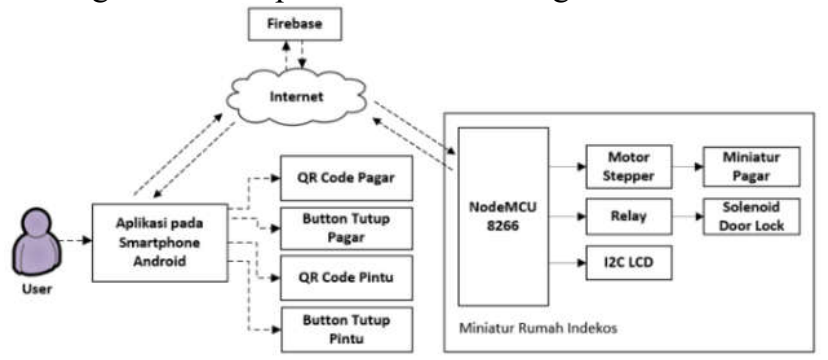

Gambar 1. Blok Diagram Miniatur Rumah Indekos

Berikut adalah keterangan mengenai masing-masing fungsi dari input maupun output sistem yang dirancang berdasarkan blok diagram dari Gambar 1:

1. User adalah yang mengoperasikan aplikasi android untuk mengakses pagar dan pintu kamar rumah indekos.

2. Aplikasi android digunakan untuk pemindaian QR Code yang ada pada pagar dan pintu kamar rumah indekos dan setiap kode QR menunjukkan identitas setiap kamar, pada aplikasi android juga terdapat sistem peringatan pembayaran indekos jika waktu sewa telah habis.

3. Untuk menutup pagar dan pintu kamar menggunakan button yang terdapat pada aplikasi android. 
4. Hasil pemindaian QR Code dikirim ke database firebase untuk diproses, dan jika data QR Code sesuai dengan data identitas penghuni indekos di database maka selanjutnya akan dikirimkan ke nodeMCU untuk menjalankan perintah.

5. Internet digunakan sebagai penghubung antara aplikasi android yang ada di smartphone dengan database firebase [10]. Sedangkan firebase digunakan sebagai tempat penyimpanan data admin dan identitas penghuni kamar indekos.

6. NodeMCU sebagai pusat kendali [11], [12] dan mengontrol sistem yang akan dirancang.

7. Relay merupakan saklar elektronik untuk mengendalikan perangkat listrik yang memerlukan tegangan dan arus [13].

8. Motor stepper berfungsi sebagai penggerak [14] miniatur pagar.

9. Prototipe pagar digunakan sebagai miniatur untuk pagar rumah indekos.

10. Solenoid doorlock sebagai sensor kunci otomatis [15] yang dapat dikontrol oleh Arduino, ini digunakan untuk membuka pintu kamar indekos.

11. I2C LCD 16x2 digunakan untuk menampilkan akses kode yang dijalankan.

\section{B. Flowchart Sistem Kerja Hardware}

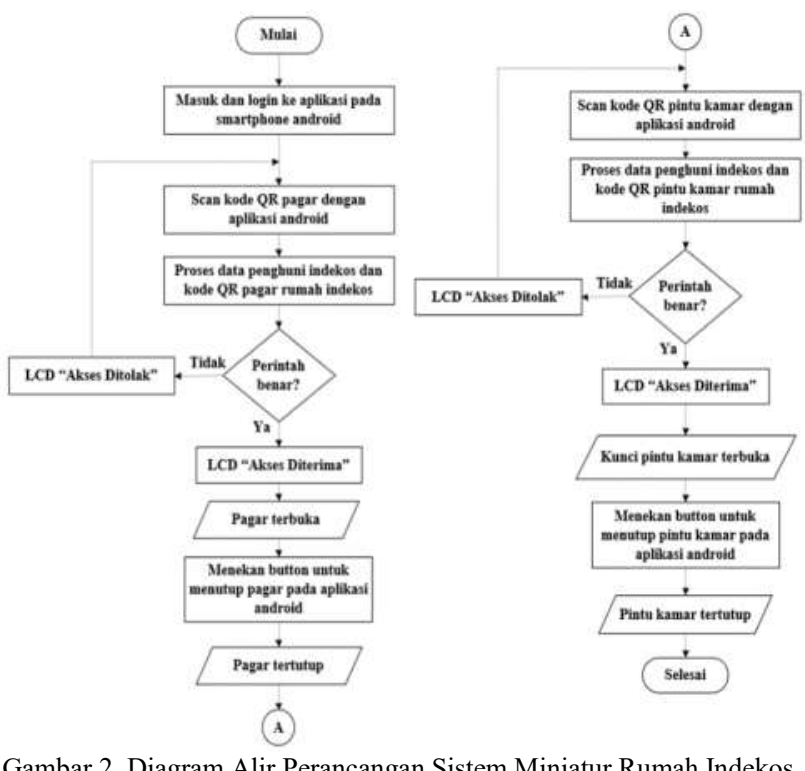

\section{Flowchart Sistem Kerja Software}
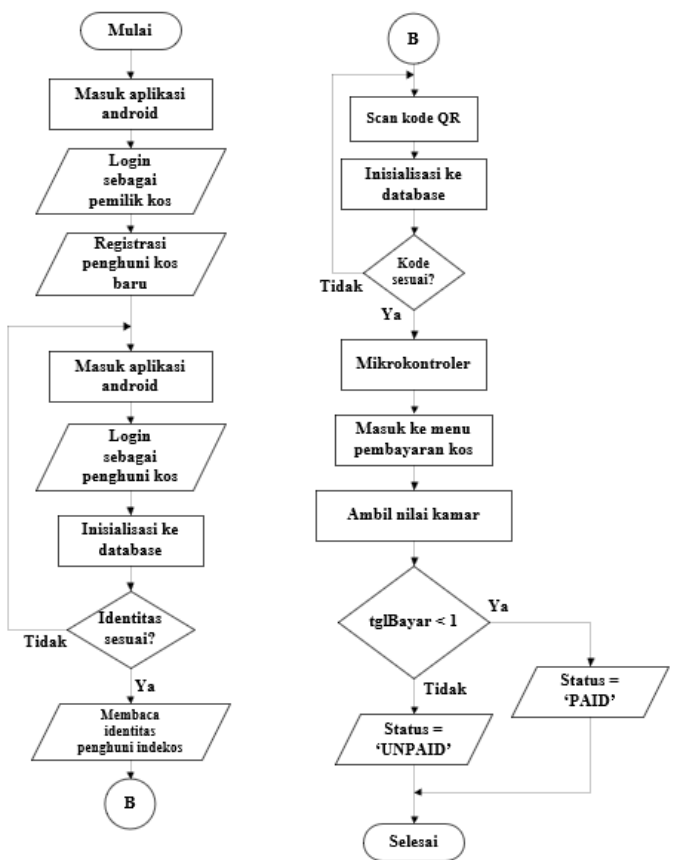

Gambar 3. Diagram Alir Perancangan Sistem Aplikasi Rumah Indekos

\section{Implementasi pada Miniatur Rumah Indekos}

Implementasi pada miniatur rumah indekos meliputi gambar rangkaian yang terhubung dengan berbagai komponen, dan program mikrokontroler untuk nodeMCU pada sistem miniatur rumah indekos. Berikut merupakan gambar rangkaian yang diimplementasikan:

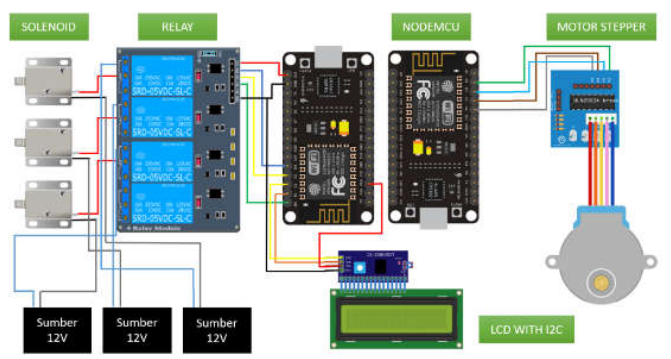

Gambar 4. Implementasi Rangkaian Miniatur Rumah Indekos

\section{HASIL DAN PEMBAHASAN}

\section{A. Hasil Perakitan dan Pembahasan Hardware}

Hasil perakitan hardware pada penelitian ini adalah berupa miniatur rumah indekos dan rangkaian komponennya. Berikut merupakan komponen yang dipasang pada miniatur rumah indekos. 


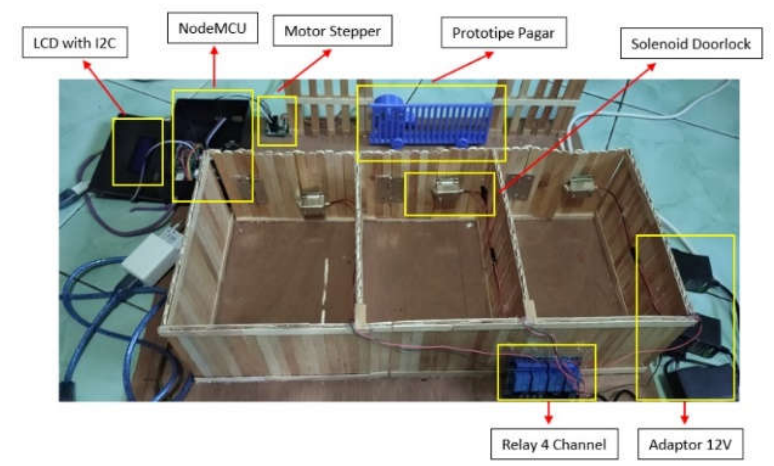

Gambar 5. Implementasi Rangkaian Miniatur Rumah Indekos

Berikut merupakan implementasi dari desain miniatur rumah indekos.

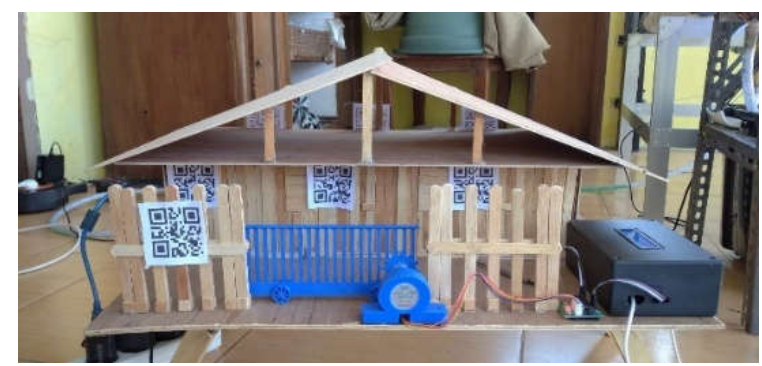

Gambar 6. Implementasi Miniatur Rumah Indekos Tampak Depan

QR Code dapat dibangkitkan dengan QR Code Generator yang dapat diakses secara online melalui https://www.theqrcode-generator.com/. Format data yang digunakan untuk pembangkitan kode QR adalah "kamar1", "kamar2", "kamar3", dan "pagarGeser". Setelah diperoleh kode QR, maka kode QR dapat disimpan dan menghasilkan data yang telah dibangkitkan menjadi kode QR seperti pada Gambar 7.

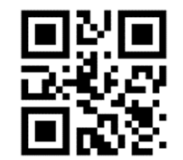

Gambar 7. Contoh Hasil Pembangkitan QR Code pagarGeser

B. Hasil Pengujian dan Pembahasan Aplikasi Android

\section{1) Tampilan Activity Pemilik dan Penghuni Indekos:}

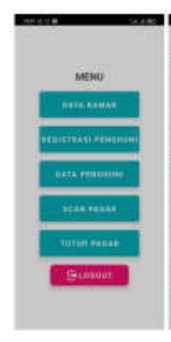

(a)

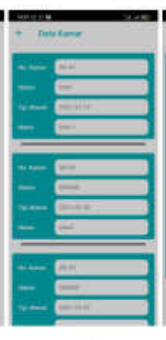

(b)

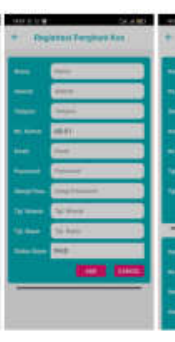

(c)

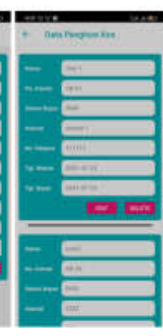

(d)

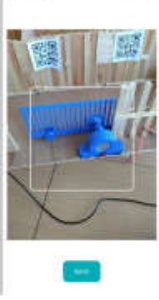

(e)

Gambar 8. a) Tampilan Activity Pemilik Indekos yaitu b) Data Kamar, c) Registrasi Penghuni, d) Data Penghuni, dan e) Pemindaian Scan Pagar

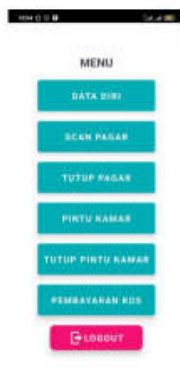

(a)

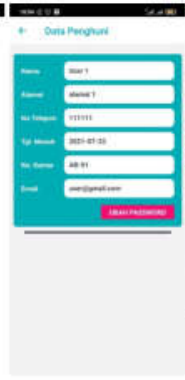

(b)

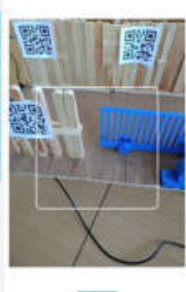

(c)

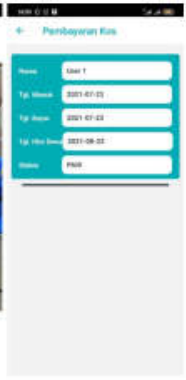

(d)
Gambar 9. a) Tampilan Activity Penghuni Indekos yaitu b) Data Diri, c) Pemindaian Scan Pagar dan Pintu Kamar, dan d) Pembayaran KosHasil Pembacaan QR Code

2) Hasil Pembacaan $Q R$ Code di Ruang Terang dengan Sinaran Lampu 20W:

TABEL I

Hasil PembacaAn QR Code Di RuANG TERANG

\begin{tabular}{cccc}
\hline No & $\begin{array}{c}\text { Jarak } \\
(\mathbf{c m})\end{array}$ & Keterangan Kode QR & $\begin{array}{c}\text { Waktu } \\
\text { (detik) }\end{array}$ \\
\hline 1 & 20 & Berhasil dan pemindaian cepat & 1 \\
\hline 2 & 30 & Berhasil dan pemindaian cepat & 1 \\
\hline 3 & 40 & Berhasil dan pemindaian cepat & 1 \\
\hline 4 & 50 & Berhasil dan pemindaian cepat & 1 \\
\hline 5 & 60 & Berhasil dan pemindaian cepat & 1 \\
\hline 6 & 70 & Berhasil dan pemindaian cepat & 1 \\
\hline 7 & 80 & Berhasil dan pemindaian cepat & 1 \\
\hline 8 & 90 & Berhasil dan pemindaian cepat & 1 \\
\hline 9 & 100 & Berhasil dan pemindaian cepat & 2 \\
\hline 10 & 110 & Berhasil dan pemindaian lama & 2 \\
\hline 11 & 120 & Berhasil dan pemindaian lama & 3 \\
\hline 12 & 130 & Tidak Berhasil & - \\
\hline
\end{tabular}

Berdasarkan data pada Tabel I pembacaan kode QR pada ruang terang hanya menjangkau $130 \mathrm{~cm}$ dengan kecepatan pemindaian minimum 1 detik dan maksimum 3 detik, di atas jarak $130 \mathrm{~cm}$ deteksi kode mulai tidak terlihat karena sensitifitas kamera smartphone yang terbatas sehingga aplikasi tidak merespon saat dilakukan pemindaian kode QR.

3) Hasil Pembacaan QR Code di Ruang Cukup Gelap dengan Lampu Tumblr Kuning $6 \mathrm{~W}$ :

TABEL II

HASIl PEMBACAAN QR CODE DI RUANG CUKUP GELAP

\begin{tabular}{cccc}
\hline No & $\begin{array}{c}\text { Jarak } \\
(\mathbf{c m})\end{array}$ & Keterangan Kode QR & $\begin{array}{c}\text { Waktu } \\
\text { (detik) }\end{array}$ \\
\hline 1 & 20 & Berhasil dan pemindaian cepat & 1 \\
\hline 2 & 30 & Berhasil dan pemindaian cepat & 1 \\
\hline 3 & 40 & Berhasil dan pemindaian lama & 2 \\
\hline 4 & 50 & Berhasil dan pemindaian lama & 3 \\
\hline 5 & 60 & Berhasil dan pemindaian lama & 4 \\
\hline 6 & 70 & Tidak Berhasil & - \\
\hline 7 & 80 & Tidak Berhasil & - \\
\hline 8 & 90 & Tidak Berhasil & - \\
\hline 9 & 100 & Tidak Berhasil & - \\
\hline 10 & 110 & Tidak Berhasil & \\
\hline
\end{tabular}

Berdasarkan data pada Tabel II adalah pembacaan kode QR di tempat yang cukup gelap hanya menjangkau dengan jarak $60 \mathrm{~cm}$ dengan kecepatan pemindaian minimum adalah 1 
detik dan maksimum 4 detik, di atas $60 \mathrm{~cm}$ kamera smartphone tidak dapat menjangkau pembacaan kode QR dikarenakan jarak yang semakin jauh dapat mengganggu pembacaan pada kode QR ketika di ruang yang cukup gelap.

4) Hasil Pembacaan QR Code dengan Sudut pada Garis Horizontal:

TABEL III

Hasil PembacaAn QR Code DENGAN Sudut

\begin{tabular}{ccc}
\hline No & Sudut $\left.\mathbf{(}^{\circ}\right)$ & Keterangan Kode QR \\
\hline 1 & 0 & Tidak Berhasil \\
\hline 2 & 10 & Tidak Berhasil \\
\hline 3 & 20 & Tidak Berhasil \\
\hline 4 & 30 & Tidak Berhasil \\
\hline 5 & 40 & Tidak Berhasil \\
\hline 6 & 50 & Tidak Berhasil \\
\hline 7 & 60 & Berhasil \\
\hline 8 & 70 & Berhasil \\
\hline 9 & 80 & Berhasil \\
\hline 10 & 90 & Berhasil \\
\hline 11 & 100 & Berhasil \\
\hline 12 & 110 & Berhasil \\
\hline 13 & 120 & Berhasil \\
\hline 14 & 130 & Tidak Berhasil \\
\hline 15 & 140 & Tidak Berhasil \\
\hline 16 & 150 & Tidak Berhasil \\
\hline 17 & 160 & Tidak Berhasil \\
\hline 18 & 170 & Tidak Berhasil \\
\hline 19 & 180 & Tidak Berhasil \\
\hline
\end{tabular}

Berdasarkan data pada Tabel III adalah sudut yang dapat dijangkau untuk pemindaian kode QR menggunakan kamera smartphone adalah pada sudut antara $60^{\circ}-120^{\circ}$, sedangkan pemindaian dengan besar sudut lain tidak berhasil.

5) Hasil Pembacaan QR Code dengan Gerakan Cepat dan Lambat:

TABEL IV

HASIL PEMBACAAN QR CODE DENGAN GERAKAN

\begin{tabular}{ccc}
\hline No & Kondisi & Keterangan Kode QR \\
\hline 1 & Gerak lambat & Berhasil \\
\hline 2 & Gerak cepat & Tidak Berhasil \\
\hline
\end{tabular}

Berdasarkan data pada tabel Tabel IV adalah ketika pemindaian kode QR dilakukan dengan gerakan lambat dan fokus ke kode QRnya, maka dapat terbaca dengan baik. Sedangkan jika pemindaian kode QR dilakukan dengan gerak cepat, maka kode QR tidak dapat terbaca dengan baik.

\section{Hasil Pengujian dan Pembahasan Quality of Service}

Pengujian kualitas komunikasi antara NodeMCU ke Firebase dilakukan 3 parameter pengujian meliputi delay, packet loss dan throughput dengan menghitung Quality of Service. Ketika pengujian QoS ini data yang dikirim yaitu paket-paket data atau informasi dalam sebuah jaringan dan protokol yang digunakan yaitu Transmission Control Protocol (TCP).

\section{1) Pengujian Delay:}

Berikut merupakan rumus dari delay rata rata :

$$
\text { Delay rata }- \text { rata }=\frac{\text { Timespan }(s)}{\text { Jumlah Paket }}
$$

Dari rumus di atas, maka dapat menghitung delay dan didapatkan hasil seperti pada Tabel V.

TABEL V

\begin{tabular}{|c|c|c|}
\hline $\begin{array}{c}\text { Pengukuran } \\
\text { ke- }\end{array}$ & Waktu & Delay (detik) \\
\hline \multirow[t]{3}{*}{1} & $15.00-16.00$ & Delay $=\frac{14.619}{26}=0.58$ \\
\hline & $17.00-18.00$ & Delay $=\frac{23.754}{12}=1.97$ \\
\hline & $19.00-20.00$ & Delay $=\frac{31.931}{10}=3.19$ \\
\hline \multirow[t]{3}{*}{2} & $15.00-16.00$ & Delay $=\frac{59.782}{32}=1.87$ \\
\hline & $17.00-18.00$ & Delay $=\frac{42.887}{19}=2.20$ \\
\hline & $19.00-20.00$ & Delay $=\frac{56.199}{15}=3.74$ \\
\hline \multirow[t]{3}{*}{3} & $15.00-16.00$ & Delay $=\frac{76.055}{30}=2.53$ \\
\hline & $17.00-18.00$ & Delay $=\frac{120.617}{31}=3.89$ \\
\hline & $19.00-20.00$ & Delay $=\frac{165.016}{51}=3.23$ \\
\hline
\end{tabular}

Delay adalah waktu yang diperlukan suatu paket untuk sampai ke tujuan. Berdasarkan hasil pengujian di atas, dapat diketahui bahwa nilai delay paling besar pukul $15.00-16.00$ yaitu pada pengukuran ke-3 dengan nilai 2,53 detik, pukul 17.00 - 18.00 memiliki nilai delay yang besar pada pengukuran ke-3 dengan nilai 3,89 detik, dan pengukuran pukul $19.00-$ 20.00 memiliki delay yang besar dengan nilai 3,74 yaitu pada pengukuran ke-2. Semakin kecil delay maka akan semakin bagus kualitas suatu pengiriman data karena tidak akan terjadi keterlambatan informasi. Hasil rata - rata delay yang diperoleh dari pengujian ini yaitu 2,57 detik dan memiliki nilai indeks 1 , hal ini ditunjukkan pada tabel kategori delay.

2) Pengujian Packet Loss:

Berikut merupakan rumus nilai packet loss:

$$
=\frac{\text { Packet Loss }(\%)}{\text { Total Packet Loss }(\text { All TCP Errors })} \times 100 \%
$$

Dari rumus diatas, maka dapat menghitung packet loss pada node pintu dan pagar. Sehingga didapatkan hasil packet loss seperti pada Tabel VI.

TABEL VI

HASIL PENGUJian PACKet Loss

\begin{tabular}{ccc}
\hline $\begin{array}{c}\text { Pengukuran } \\
\text { ke- }\end{array}$ & Waktu & \multicolumn{1}{c}{ Packet Loss } \\
\hline $\mathbf{1}$ & $15.00-16.00$ & Packet Loss \\
& & $=\frac{2}{1108} \times 100 \%=0.18 \%$ \\
\hline
\end{tabular}


Jurnal Jaringan Telekomunikasi E-ISSN:2654-6531 P- ISSN: 2407-0807 Vol. 11, No.4 (2021) 175-181

\begin{tabular}{|c|c|c|}
\hline $\begin{array}{l}\text { Pengukuran } \\
\text { ke- }\end{array}$ & Waktu & Packet Loss \\
\hline & $17.00-18.00$ & $\begin{array}{l}\text { Packet Loss } \\
=\frac{2}{3712} \times 100 \%=0.05 \%\end{array}$ \\
\hline & $19.00-20.00$ & $\begin{array}{l}\text { Packet Loss } \\
=\frac{2}{1494} \times 100 \%=0.13 \%\end{array}$ \\
\hline \multirow[t]{4}{*}{2} & $15.00-16.00$ & $\begin{array}{l}\text { Packet Loss } \\
=\frac{2}{17-0} \times 100 \%=0.11 \%\end{array}$ \\
\hline & & 1778 \\
\hline & $17.00-18.00$ & $\begin{array}{l}\text { Packet Loss } \\
=\frac{2}{1512} \times 100 \%=0.13 \%\end{array}$ \\
\hline & $19.00-20.00$ & $\begin{array}{l}\text { Packet Loss }=\frac{2}{862} \times 100 \% \\
=0.23 \%\end{array}$ \\
\hline \multirow[t]{3}{*}{3} & $15.00-16.00$ & $\begin{array}{l}\text { Packet Loss } \\
=\frac{2}{2658} \times 100 \%=0.07 \%\end{array}$ \\
\hline & $17.00-18.00$ & $\begin{array}{l}\text { Packet Loss } \\
=\frac{2}{3719} \times 100 \%=0.05 \%\end{array}$ \\
\hline & $19.00-20.00$ & $\begin{array}{l}\text { Packet Loss } \\
=\frac{2}{4088} \times 100 \%=0.04 \%\end{array}$ \\
\hline
\end{tabular}

Berdasarkan hasil pengujian di atas, dapat diketahui bahwa nilai packet loss paling besar pukul $15.00-16.00$ yaitu pada pengukuran ke-1 dengan nilai $0,18 \%$, pukul $17.00-18.00$ memiliki nilai packet loss yang besar pada pengukuran ke-2 dengan nilai $0,13 \%$, dan pengukuran pukul $19.00-20.00$ memiliki packet loss yang besar dengan nilai $0,23 \%$ yaitu pada pengukuran ke-2. Rata - rata dari pengujian pukul $15.00-$ 16.00 adalah $0,12 \%$, pukul $17.00-18.00$ adalah $0,076 \%$, dan pukul $19.00-20.00$ adalah $0,13 \%$. Hasil rata - rata packet loss yang diperoleh dari pengujian ini memiliki nilai indeks 4 , hal ini ditunjukkan pada tabel kategori packet loss.

\section{3) Pengujian Throughput:}

Berikut merupakan rumus untuk mendapatkan nilai throughput:

$$
\text { Throughput }=\frac{\text { Bytes }}{\text { Timespan }} \times 8
$$

Dari rumus di atas, maka dapat menghitung throughput pada node pagar dan pintu. Sehingga didapatkan hasil throughput seperti pada Tabel VII.

Tabel VII

Hasil Pengujian Throughput

\begin{tabular}{clc}
$\begin{array}{c}\text { Pengukuran } \\
\text { ke- }\end{array}$ & \multicolumn{1}{c}{ Waktu } & Throughput (bps) \\
\hline $\mathbf{1}$ & $15.00-$ & Thrg $=\frac{2182766}{554.436} \times 8=31495$ \\
& 16.00 & Thrg $=\frac{2570299}{579.395} \times 8=35489$ \\
& $17.00-$ & Thrg $=\frac{2746841}{609.425} \times 8=36058$ \\
& 18.00 & Thrg $=\frac{3045272}{709.938} \times 8=34315$ \\
\hline $\mathbf{2}$ & $19.00-$ & Thrg $=\frac{3130557}{798.407} \times 8=31368$ \\
\hline
\end{tabular}

\begin{tabular}{clc}
\hline $\begin{array}{c}\text { Pengukuran } \\
\text { ke- }\end{array}$ & Waktu & Throughput (bps) \\
\hline & $19.00-$ & Thrg $=\frac{2976045}{721.815} \times 8=32984$ \\
& 20.00 & Thrg $=\frac{3045672}{555.475} \times 8=43864$ \\
\hline 3 & $15.00-$ & Thrg $=\frac{2895302}{664.975} \times 8=34832$ \\
& 16.00 & Thrg $=\frac{2873083}{607.281} \times 8=31904$ \\
& $17.00-$ & \\
& 18.00 & \\
& $20.00-$ &
\end{tabular}

Berdasarkan hasil pengujian di atas, dapat diketahui bahwa nilai throughput paling besar pukul $15.00-16.00$ yaitu pada pengukuran ke-3 dengan nilai 43864 bps, pukul 17.00 18.00 memiliki nilai throughput yang besar pada pengukuran ke-1 dengan nilai 35489 bps, dan pengukuran pukul $19.00-$ 20.00 memiliki throughput yang besar dengan nilai 36058 bps yaitu pada pengukuran ke-1. Semakin tinggi nilai throughput, maka performansi pada jaringan juga bagus. Hasil rata - rata throughput yang diperoleh dari pengujian ini memiliki nilai indeks 4, hal ini ditunjukkan pada tabel kategori throughput.

\section{KESIMPULAN}

Berdasarkan perancangan, implementasi, dan pengujian pada penelitian ini, diperoleh kesimpulan bahwa miniatur rumah indekos dibuat dan dirancang menggunakan stik es krim dan papan triplek yang terdapat 3 buah kamar dan satu miniatur pagar yang masing-masing telah tertempel kode QR yang telah dicetak. Untuk pembangkitan kode QR dilakukan melalui aplikasi online dengan format \{"kamar1","kamar2","kamar3","pagarGeser"\}. Komponen alat yang dibutuhkan berupa NodeMCU, solenoid doorlock, relay 4 channel, motor stepper dan LCD, semua komponen dihubungkan menggunakan jumper dan diberi catu daya untuk dipasang ke miniatur rumah indekos yang telah dibuat, dengan begitu sistem sudah bisa dijalankan.

Komunikasi antar node pagar dengan node pintu kamar pada miniatur rumah indekos dilakukan dengan melakukan pengujian Quality of Service (Qos) untuk pengukuran tentang seberapa baik jaringan ketika sistem dijalankan, pengukuran kualitas layanan yang digunakan meliputi delay, packet loss, dan throughput. Pengukuran dilakukan menggunakan software wireshark.

Keberhasilan uji fungsionalitas miniatur rumah indekos yang telah dibuat yaitu dengan menguji fungsionalitas dari aplikasi SmartKos pada smartphone android, database firebase, dan keakuratan komunikasi data antara firebase dan NodeMCU berupa delay dengan nilai terburuk pada pengukuran ke-3 dengan nilai 3.89 detik, throughput yang paling baik adalah pada pengukuran ke-3 dengan nilai 43864 bps, packet loss pada penelitian ini memiliki indeks 4 karena memiliki nilai packet loss sebesar $0 \%$.

\section{REFERENSI}

[1] "indekos," KBBI Daring, 2016. https://kbbi.kemdikbud.go.id/entri/indekos (accessed Jul. 26, 2021). 
[2] P. Utomo, "Dinamika Pelajar Dan Mahasiswa Di Sekitar Kampus Yogyakarta ( Telaah Pengelolaan Rumah Kontrak Dan Rumah Sewa )," Univ. Negeri Yogyakarta, no. April, pp. 11-14, 2009.

[3] A. R. Gifari Alim Prakasa, "Prototype Sistem Kunci Pintu Berbasis QR Code dan Arduino," 2017.

[4] T. K. A. Ahmad, "Implementasi IoT Sebagai Monitoring Sistem Pembayaran Uang Kos Berbasis Android", Jaringan Telekomunikasi, vol. 10, no. 1, hlm. 60-70, Mar 2020.

[5] D. Nataliana, S. Anwari, dan M. S. Akbar, "Implementasi Prototype Sistem Home security dengan Pemanfaatan Kode Akses berbasis Arduino Mega," ELKOMIKA J. Tek. Energi Elektr. Tek. Telekomun. Tek. Elektron., vol. 5, no. 2, p. 119, 2018, doi: 10.26760/elkomika.v5i2.119.

[6] A. Siswanto, A. Efendi, and A. Yulianti, "Alat Kontrol Akses Pintu Rumah Dengan Teknologi Sidik Jari Di Lingkungan Rumah Pintar Dengan Data Yang Di Enkripsi,” J. Penelit. Pos dan Inform., vol. 8, no. 2, p. 97, 2018, doi: 10.17933/jppi.2018.080201.

[7] N. Lestari, "Rancang Bangun Pintu Otomatis Menggunakan Arduino Uno Dan PIR (Passive Infra Red) Sensor Di SMP Negeri Simpang Semambang," J. Chem. Inf. Model., vol. 53, no. 9, pp. 1689-1699, 2017.

[8] A. F. Silvia, E. Haritman, and Y. Muladi, "Rancang Bangun Akses Kontrol Pintu Gerbang Berbasis Arduino Dan Android," Electrans, vol. 13, no. 1, pp. 1-10, 2014.

[9] E. Hamid, L. Chong, N. Bahaman, S. Anawar, Z. Ayob, and A. Abdul, "Implementation of Intelligent Automated Gate System with QR Code," Int. J. Adv. Comput. Sci. Appl., vol. 9, no. 10, pp. 359-363, 2018, doi: 10.14569/ijacsa.2018.091043.

[10]E. W. Ula, "Rancang Bangun Aplikasi Sistem Keamanan Loker Dosen Menggunakan Kode QR,” Politeknik Negeri Malang, 2019.

[11] Mikrokontroller, "Sistem kendali," Jte, vol. 8, no. 2, pp. 25-34, 2004.

[12] A. Nurbaeti, M. Kusumawardani, dan H. Darmono, "Rancang Bangun Alat Pengering Biji Kopi Berbasis Internet Of Things", Jaringan Telekomunikasi, vol. 11, no. 2, hlm. 74-80, Jun 2021.

[13]F. A. Romana, M. A. . Anshori, dan M. Junus, "Prototype Telecontrolling Pintu Air Otomatis pada Pengairan Lahan Berbasis Android", Jaringan Telekomunikasi, vol. 11, no. 1, hlm. 1-5, Mar 2021.

[14] M. P. Y. Santoso, "Perancangan Sistem Keamanan Central Lock Mobil Menggunakan Identifikasi E-KTP”, Jaringan Telekomunikasi, vol. 9, no. 4, hlm. 1-7, Des 2019.

[15] M. H. Fuadi, "Rancang Bangun Kontrol dan Monitoring Suhu Pada Mesin Diesel Menggunakan Mobile”, Jaringan Telekomunikasi, vol. 10, no. 1, hlm. 31-37, Mar 2020. 